\title{
Nilai-Nilai Budaya Sasak Kemidi Rudat Lombok: Perspektif Hermeneutika
}

\author{
Murahim $^{1}$
}

\begin{abstract}
Abstrak
Penelitian ini merumuskan masalah nilai-nilai budaya yang diekspresikan melalui pementasan Kemidi Rudat Lombok yang meliputi (1) nilai-nilai religius yang diekspresikan melalui pementasan Kemidi Rudat Lombok, (2) nilai-nilai filosofis yang diekspresikan melalui pementasan Kemidi Rudat Lombok, (3) nilai-nilai etis yang diekspresikan melalui pementasan Kemidi Rudat Lombok, dan (4) nilai-nilai estetis yang diekspresikan melalui pementasan Kemidi Rudat Lombok. Penelitian ini bertujuan untuk mendeskripsikan nilai-nilai budaya Sasak dalam seni teater tradisional Kemidi Rudat Lombok. Nilai-nilai budaya yang dimaksud adalah (1) nilai religius; (2) nilai filosofis,; (3) nilai etis; dan (4) nilai estetis. Penelitian ini menggunakan pendekatan hermeneutika, yaitu penafsiran secara mendalam terhadap sebuah fenomena budaya. Pendekatan ini memiliki kaidah: (1) dibutuhkan keterlibatan dan atau partisipasi; (2) setiap usaha penafsiran, tidak bisa dihindari adanya akibat ikutan dari partisipasi dan latar belakang penafsir; (3) upaya penafsiran harus dilihat sebagai proses pendekatan kepada makna sejati; (4) walaupun ada wilayah perbedaan karena partisipasi dan latar belakang penafsir, niscaya ada pula wilayah yang mempertemukan antarpenafsir, pemahaman bersama terhadap suatu masalah. Dari hasil penelitian ini ditemukan bahwa Kemidi Rudat terdiri dari dua bagian penting, yaitu bagian rudat sebagai bagian pembuka dan kemidi sebagai bagian inti yang merupakan bagian pementasan yang menyajikan cerita tentang perjalanan dua kerajaan, yaitu kerajaan Ginter Baya dengan Raja Indra Bumaya sebagai rajanya dan kerajaan Puspasari dengan Sultan Ahmad Mansyur sebagai rajanya. Cerita tersebut diberi judul "Prahara di Ginter Baya". Nilai-nilai budaya yang berupa nilai religius, filosofis, etis, dan estetis ditemukan dalam dialog-dialog antartokoh, perilaku tokoh, dan sikap tubuh para pemain. Semua nilai budaya yang ditemukan dihubungkan dengan sistem nilai dasar dalam masyarakat Sasak, hukum adat dan kitab tembang suluk berbahasa Sasak "Tapel Adam" yang banyak berisi nilai-nilai kebijaksanaan hidup manusia Sasak.
\end{abstract}

Kata kunci: nilai budaya, Sasak, Kemidi Rudat.

\footnotetext{
${ }^{1}$ Pengajar pada FKIP Universitas Mataram
} 


\section{Pendahuluan}

Setiap daerah memiliki satu bentuk kesenian yang menjadi identitas daerah tersebut. Masing-masing bentuk kesenian daerah merupakan ciri khas dan menjadi corak budaya daerah asal kesenian itu. Oleh karena itu, kesenian daerah merupakan puncak-puncak budaya yang terdapat di daerah dan menjadi simbol masyarakat pemiliknya. Terciptanya suatu kesenian (pertunjukan) secara konseptual akan berpedoman pada sistem nilai budaya yang mengelilinginya dan khas sesuai dengan budaya daerah tersebut (Bandem, 1988:50).

Kemidi Rudat adalah salah satu jenis teater tradisional yang sudah berakar dan menjadi milik masyarakat suku Sasak di Pulau Lombok, Nusa Tenggara Barat. Kemidi Rudat merupakan seni tradisional bernafaskan Islam yang diserap dari kebudayaan Arab (Turki). Dari latar belakang sejarahnya, Kemidi Rudat diciptakan oleh seorang haji yang baru pulang dari Mekkah. Secara fisik, jenis kesenian ini menggambarkan kegagahan prajurit Turki (Islam) lengkap dengan seragam tentara. Nuansa Timur Tengah dalam kesenian rudat ini menjadi karakter dan ciri yang menonjol. Hal ini tampak dari pakaian khas para pemain dan lagu-lagu pengiring yang digunakan dalam pertunjukan teater ini. Pakaian pemain mirip dengan seragam serdadu kerajaan Turki tempo dulu (bahkan mirip seragam kompeni Belanda) dan menggunakan topi Tarbus, topi khas Turki yang dapat dilihat juga pada tokoh Aladin atau saudagarsaudagar Arab dalam film-film atau pertunjukan dengan tema dunia padang pasir.

Lagu-lagu pengiring dalam pertunjukan Kemidi Rudat berirama padang pasir dan sebagian besar menggunakan syair dalam bahasa Arab yang lafalnya terkadang tidak jelas lagi karena terpengaruh lafal bahasa ucap orang Sasak. Sebagian lagi ada yang menggunakan bahasa Indonesia (melayu), tetapi tetap dengan irama padang pasir. Lagu-lagu tersebut antara lain; fi qur'ani, mahmud sungkar, ilal fajri, al pisal, abda'u, ya robbuna, dan ilahi sebagai lagu berbahasa Arab. Lagu-lagu dalam bahasa Indonesia, antara lain selamat datang, tabek tuan, mawar merah, pemuda Muhammadin, nabi Adam, dan sebagainya. Dengan demikian, tidaklah salah apabila seni teater Kemidi Rudat dikategorikan sebagai jenis kesenian yang bersumber kepada kebudayaan Melayu-Islam.

Beberapa ciri khas Kemidi Rudat di atas menjadi keunikan tersendiri karena telah dianggap menjadi milik masyarakat suku Sasak Lombok. Hal ini tidak bisa dilepaskan dari peranan pementasan Kemidi Rudat ini sebagai media dakwah Islam karena cerita yang ditampilkan menggambarkan kemenangan 
yang haq atas yang bathil. Masyarakat suku Sasak yang mayoritas beragama Islam menjadi sangat mudah menerimanya. Pertunjukan Kemidi Rudat ini juga berperan sebagai media hiburan masyarakat untuk memeriahkan pestapesta/upacara adat, seperti khitanan, upacara perkawinan, selamatan atas panen yang berhasil, dan lain sebagainya.

Teater tradisional mengandung nilai-nilai dan kearifan lokal yang menjadi cermin perilaku masyarakat pendukungnya. Nilai-nilai budaya dan kearifan lokal yang ada dalam teater tradisional tersebut bisa dijadikan pedoman perilaku dalam hidup bermasyarakat, mengetahui mana yang baik dan mana yang buruk sesuai budaya dan warisan leluhur masyarakat pendukungnya. Nilai-nilai budaya dan kearifan lokal dalam teater tradisional perlu diketahui untuk dijadikan sebagai filter atau penyeimbang nilai-nilai kebudayaan modern yang tidak sesuai dengan budaya dan etika masyarakat pendukung teater tradisional tersebut. Persoalan yang muncul adalah nilai-nilai budaya apa saja yang terdapat dalam seni pertunjukan (teater tradisional) itu sehingga masyarakat mempertahankannya sampai sekarang. Untuk itu, pengenalan terhadap nilai-nilai budaya masyarakat yang terdapat dalam teater tradisional terhadap generasi muda perlu dilakukan.

Teater tradisional juga merupakan bagian identitas masyarakat pendukungnya. Mengenal karakter suatu masyarakat bisa dilakukan dengan mengenal dan mengetahui kesenian yang berkembang dalam masyarakat tersebut. Mengenal komunitas suku Sasak bisa dilakukan dengan mengenal dan mengetahui bahwa Kemidi Rudat adalah kesenian khas suku Sasak yang mencerminkan nilai-nilai yang dianut oleh masyarakat Sasak. Bila bagian identitas ini hilang, maka secara perlahan kita juga tidak bisa mengenal budaya dan kearifan lokal yang ada dan berkembang dalam masyarakat suku Sasak. Jika kasus tersebut terjadi dan sebagai bagian dari suku Sasak, seseorang tidak lagi mengenal diri sendiri. Sebagaimana orang Sasak mengatakan maraq manuk bekesena (seperti ayam di depan cermin), hanya mematuk-matuk bayangan di cermin (disangka musuh) karena tidak lagi mengenal bahwa bayangan tersebut adalah bayangannya sendiri.

Sebagai pertunjukan seni yang mengandung dakwah Islam, Kemidi Rudat bisa diterima dengan baik oleh masyarakat suku Sasak bahkan telah berkembang dan menjadi milik dan kebudayaan masyarakat Sasak yang sebagian besar beragama Islam. Sikap terbuka masyarakat Sasak ini juga tidak lepas dari nilai yang terkandung dalam kesenian Kemidi Rudat yang sesuai 
dengan nilai dan kearifan lokal masyarakat suku Sasak Lombok. Nilai-nilai budaya yang terdapat atau diusung dalam pertunjukan Kemidi Rudat dianggap dapat mencerminkan jati diri dan identitas masyarakat suku Sasak.

Kajian terhadap nilai dalam Kemidi Rudat berhubungan dengan substansi nilai yang meliputi (a) nilai religius, (b) nilai filosofis, (c) nilai etis, dan (d) nilai estetis. Keempat nilai tersebut mencerminkan akal budi dan cara pandang masyarakat suku Sasak secara mikro dan makro dalam berkomunikasi dengan Tuhan, berkomunikasi dengan sesama manusia, dan berkomunikasi dengan alam lingkungan hidup. Pelestarian kesenian Kemidi Rudat ini adalah juga pelestarian terhadap nilai-nilai budaya Sasak yang terkandung di dalamnya.

Nilai-nilai religius menempati peringkat yang sangat tinggi dalam kehidupan seorang yang beradab. Dikatakan demikian karena nilai-nilai religius berkaitan dengan kebenaran Ilahi yang bersifat absolut dan universal yang berangkat dari dan bermuara pada hak asasi manusia yang paling asasi, yaitu hubungan seseorang dengan pencipta-Nya. Dalam Islam, hubungan itu diwujudkan dengan penerapan akidah, ibadah, dan muamalah sesuai dengan petunjuk dalam Al-Quran dan Hadits Rasulullah Saw.

Nilai-nilai filosofis adalah suatu keyakinan mengenai cara bertingkah laku dan tujuan akhir yang diinginkan individu. Nilai tersebut digunakan sebagai prinsip atau standar dalam hidup yang terdapat dalam pandangan hidup seseorang atau sekelompok orang yang merupakan konsep dasar mengenai kehidupan yang dicita-citakan. Filosofi hidup orang Sasak tidak bisa dilepaskan dari nama Sasak sendiri. Sasak Lombok mempunyai kaitan yang erat sehingga tidak dapat dipisahkan. Ia terjalin menjadi satu, yang berasal dari kata " $S a$ 'sa' Lomboq" yang berasal dari sa'= satu dan lomboq' = lurus. Maka, Sasak Lombok berarti satu-satunya kelurusan. Artinya, orang Sasak Lombok adalah orang yang menjunjung tinggi kelurusan/kejujuran/polos.

Etika adalah aturan perilaku, adat kebiasaan manusia dalam pergaulan antara sesamanya dan menegaskan mana yang benar dan mana yang buruk. Perkataan etika atau lazim juga disebut etis berasal dari kata Yunani, ethos, yang berarti norma-norma, nilai-nilai, kaidah-kaidah dan ukuran-ukuran bagi tingkah laku manusia yang baik. Nilai etis adalah nilai yang menjadi pedoman perilaku dalam pergaulan dengan sesama manusia.

Nilai estetis adalah nilai yang berhubungan dengan segala sesuatu yang tercakup dalam pengertian keindahan. Dalam hal ini, keindahan dianggap searti dengan nilai estetis pada umumnya. Apabila suatu benda disebut indah, 
sebutan itu tidak menunjuk pada suatu ciri seperti umpamanya keseimbangan atau sebagai penilaian subjektif saja, melainkan menyangkut ukuran-ukuran nilai yang bersangkutan. Ukuran-ukuran nilai itu tidak selalu sama untuk masing-masing karya seni, bermacam-macam alasan; karena manfaat, langkah atau karena coraknya yang spesifik (Dharsono, 2007:8).

Konsepsi nilai-nilai di atas merupakan dasar yang menjadi pedoman penelitian ini. Bagaimana nilai-nilai tersebut terekspresikan melalui pertunjukan teater tradisional Kemidi Rudat di pulau Lombok. Nilai-nilai tersebut dihubungkan dengan kebiasaan dan perilaku masyarakat Sasak yang merupakan suku asli pulau Lombok. Penelitian ini ingin mengungkap nilai-nilai dan kearifan masyarakat Sasak yang terekspresikan melalui Kemidi Rudat.

\section{Metode Penelitian}

\subsection{Jenis dan Pendekatan Penelitian}

Penelitian ini merupakan jenis penelitian deskriptif-kualitatif. Hal ini sejalan dengan pendapat Mulyana (2002:158) yang mengemukakan ciri-ciri penelitian kualitatif, yaitu (a) memiliki pijakan teoretis pada proses interpretasi manusia, (b) memfokuskan perhatian pada studi tindakan dan artefak (tekstual), (c) menggunakan manusia sebagai instrumen penelitian utama, dan (d) mengandalkan terutama bentuk-bentuk naratif.

Penelitian ini disusun berdasarkan karakteristik yang berorientasi pada upaya pemerolehan informasi tentang fenomena tertentu secara sistematik, faktual, dan akurat dengan kondisi apa adanya (deskriptif). Penelitian ini juga bersifat kualitatif dengan karakteristik: data berlatar alamiah, manusia sebagai instrumen untuk menangkap makna, interaksi nilai, dan nilai lokal yang berbeda. Data berupa transkrip hasil perekaman (video), catatan lapangan, transkrip hasil wawancara, dokumen pribadi, dan lain-lain. Desain yang digunakan bersifat sementara. Hal itu disebabkan oleh adanya realitas ganda yang sulit dikerangkakan, pola lapangan yang sulit dibakukan, banyaknya sistem nilai yang terkait, dan interaksi berbagai hal yang tidak terduga.

\subsection{Data dan Sumber Data}

Data dalam penelitian ini adalah nilai-nilai budaya Sasak dalam Kemidi Rudat Lombok yang dipentaskan oleh kelompok Kemidi Rudat Desa Terengan, Pemenang Timur, Lombok Barat. Data berupa ekspresi nilai dalam teks pertunjukan dan elemen pemanggungannya. Data tersebut didasarkan pada hasil perekaman dan pengamatan di lapangan. 
Sumber data dalam penelitian ini adalah pementasan Kemidi Rudat dan penutur atau pemain yang terlibat dalam seni lakon tradisional Kemidi Rudat Lombok. Informan yaitu seniman pemilik seni tradisional Kemidi Rudat Terengan (tiga orang) dan seorang seniman akademis serta seorang budayawan Sasak. Selain itu, digunakan juga sumber data berupa dokumen berupa naskah baku pementasan Kemidi Rudat di Kampung Terengan. Informan dalam penelitian ini adalah seniman dan budayawan yang memiliki pandanganpandangan luas tentang kebudayaan masyarakat Sasak dan teater tradisi, khususnya Kemidi Rudat serta memiliki wawasan tentang seni pertunjukan secara umum.

\subsection{Teknik Pengumpulan Data}

Pengumpulan data dilakukan selama 3 (tiga) bulan yang dimulai pada bulan Maret hingga Juni tahun 2010. Teknik pengumpulan data dilakukan dengan beberapa tahap. Pertama, melakukan pengamatan dan perekaman pementasan Kemidi Rudat pada tanggal 22 Mei 2010. Hasil perekaman selanjutnya ditranskripsikan kemudian diklasifikasikan tipologinya: nilai religius, filosofis, etis, dan estetis. Kedua, melakukan wawancara. Wawancara dengan seorang budayawan Sasak dilakukan intensif sejak April hingga Juni 2010, sedangkan wawancara bersama seorang seniman akademik (sarjana teater) dilaksanakan 3 (tiga) kali selama bulan April 2010. Selain itu, wawancara bersama pemilik dan sutradara pementasan Kemidi Rudat di Kampung Terengan dilakukan sebanyak 4 (empat) kali pertemuan selama bulan April hingga malam pementasan tanggal 22 Mei 2010. Wawancara terhadap informan dilakukan untuk menjaring data pendukung yang berhubungan dengan agama, kepercayaan, kehidupan sosial, struktur masyarakat, dan lain-lain. Ketiga, studi dokumentasi yang dilakukan dengan membaca dan memahami naskah yang menjadi pedoman pementasan Kemidi Rudat Terengan yang diperoleh dari Perpustakaan Bidang Kesenian Dinas Kebudayaan dan Pariwisata. Studi dokumentasi dilakukan untuk memperoleh informasi tambahan mengenai hal-hal yang berhubungan dengan data dan subjek penelitian. Dokumentasi berupa bahan tertulis dan perekaman, hasil wawancara dengan informan dan naskah pendukung pertunjukan/pementasan.

Teknik tersebut diterapkan dengan tetap memperhatikan ciri khas dan prosedur penelitian kualitatif. Oleh karena itu, data dipilih sesuai keperluan, kecukupan, kemendalaman, dan kemenyeluruhan (Saryono, 1998). Dengan demikian, data yang diperlukan dapat ditelaah secara komprehensif. 


\subsection{Teknik Analisis Data}

Analisis data dilakukan dengan terlebih dahulu menata secara sistematis hasil rekaman, pengamatan, dan wawancara agar diperoleh deskripsi data yang utuh dan runtut (Lincoln dan Guba, 1985). Data yang diperoleh/terkumpul diolah dengan prosedur sebagai berikut.

1. Data rekaman ditranskripsi ke dalam bentuk tulisan.

2. Memilah data sesuai dengan indikator nilai yang dicari. Hal ini dilakukan dengan cara:

a. pembacaan data berulang-ulang;

b. pemberian tanda terhadap kata, kalimat, atau ungkapan yang diperkirakan mengandung hal-hal yang dicari; dan

c. pembuatan klasifikasi berdasarkan nilai-nilai yang diteliti.

\section{Hasil dan Pembahasan}

Pementasan Kemidi Rudat yang menjadi dasar pengambilan data penelitian ini adalah kelompok Kemidi Rudat "Setia Budi" di Kampung Terengan, Desa Pemenang Timur, Kabupaten Lombok Utara oleh pada tanggal 22 Mei 2010. Pementasan ini terdiri atas dua bagian. (1) Rudat merupakan tarian dengan gerakan pencak silat dan ketangkasan yang disertai lagu. Setiap lagu mempunyai fungsi masing-masing bagi pemain/penari rudat maupun penonton. Bagian pertama ini adalah bagian pembuka rangkaian pementasan. Sekitar sepuluh lagu dan gerak ditampilkan pada bagian ini. (2) Kemidi adalah bagian inti dari Kemidi Rudat yang menyajikan cerita/drama Kemidi Rudat. Cerita yang disajikan adalah cerita tentang peperangan Raja Indra Bumaya dari negeri Ginter Baya melawan Sultan Ahmad Mansyur dari negeri Puspasari.

Bagian pertama, tarian Rudat, berisi gerakan-gerakan tari yang terdiri dari beberapa bagian. (1) Lagu dan gerak selamat datang yang merupakan lagu pembuka yang dinyanyikan pada saat layar dibuka untuk mengiringi masuknya pemain/penari rudat. Lagu pembuka ini adalah lagu ucapan selamat datang dan penghormatan serta penghargaan kepada penonton yang berkenan menyaksikan pementasan Kemidi Rudat ini. (2) Tarian pembuka, yaitu tarian yang dilakukan oleh Komandan Rudat di tengah-tengah pentas yang dikelilingi oleh penari Rudat lainnya. (3) Baris-berbaris, Komandan Rudat kembali ke depan untuk mengatur barisan anak rudat dan memberi aba-aba untuk kembali membentuk barisan rudat seperti pada awal masuk. Komandan rudat memberi aba-aba baris- 
berbaris dengan menggunakan bahasa Arab dan Belanda. Bahasa yang digunakan dalam baris berbaris ini merupakan bahasa turun temurun dalam pementasan Kemidi Rudat Kampung Terengan. Bahasa Belanda yang digunakan baik dari kata-kata dan maknanya tidak seorang pemain rudat pun yang mengetahuinya. Pemain lama yang sudah sepuh pun tidak memahaminya. (4) Lagu dan gerak penghormatan, penari rudat memperagakan keterampilan menari sambil melakukan gerakan penghormatan dan pernyataan permisi kepada penonton. (5) Salam penutup, Komandan Rudat kembali mengatur barisan pemain rudat. Setelah rapi, Komandan Rudat dan wakilnya kembali ke dalam barisan, bergabung dengan pemain rudat yang lain. Setelah berbaris rapi, lagu salam penutup mulai mengalun dan langsung disambut dengan tarian oleh seluruh pemain rudat. (6) Gerak inti, pada lagu dan langkah rudat selanjutnya adalah mulainya permainan inti tarian rudat. dilaksanakan setelah beristirahat sekitar 15 menit. Anak rudat berbaris dua mengiringi kedua komandan rudat beraksi menari di tengah, keduanya menari menggunakan atau sambil memainkan pedang. Di akhir tarian, komandan rudat kembali melepas pedang dan memimpin kembali anak rudat menari bersama. Lagu-lagu yang dinyanyikan dan tarian pada bagian inti pembuka pementasan Kemidi Rudat ini adalah lagu-lagu berbahasa Arab yang diambil dari kitab Barzanzi. Lagu-lagu tersebut antara lain ya robbuna, abda'u, solatullah, lihamsatun, iza zalla, ilahi ya karim, abdikal mahya, ya robbisa, illatan sani, illahi, dan lain-lain. (7) Gerak penutup, pada bagian akhir tarian, sebagian pemain membuka topi tarbus pemain lain dan menari, sementara pemain yang tidak bertopi lagi hanya menari duduk sambil memainkan tangan. Setelah tarian selesai, sebagian pemain (yang tidak bertopi) berdiri dan melakukan hal yang sama dengan yang dilakukan pemain sebelumnya. Dibukanya topi tarbus adalah tanda berakhirnya persembahan rudat dan persiapan untuk pementasan Kemidi Rudat.

Setiap gerakan tarian rudat pada bagian awal ini tematis, gerak dan lagu selamat datang dilakukan sebagai isyarat rasa terima kasih dan penghargaan kepada penonton yang datang menyaksikan apa yang akan mereka pertunjukkan. Begitu juga dengan gerakan-gerakan selanjutnya dilakukan sebagai bentuk rasa hormat dan syukur kepada hadirin penonton dan kepada Allah Yang Maha Esa hingga pementasan dapat dilaksanakan. Beberapa tarian awal ini berfungsi sebagai pembuka pementasan Kemidi Rudat dan ucapan selamat datang dan penghargaan serta ungkapan rasa terima kasih kepada hadirin penonton dan rasa syukur kepada Allah Yang Maha Esa. 
Bagian kedua adalah pementasan Kemidi Rudat yang terdiri atas empat babak dengan beberapa adegan. Diawali dengan cerita Raja Indra Bumaya yang berkuasa di kerajaan Ginter Baya dengan diselingi kisah Putri Indra Dewi. Berlanjut dengan kisah kerajaan lain, yaitu Kerajaan Puspasari dengan Sultan Ahmad Mansyur sebagai rajanya. Kedua kerajaan ini hidup damai tanpa saling mengetahui hingga terjadi peperangan setelah Raja Indra Bumaya mengetahui ada kerajaan lain selain kerajaannya. Perang terjadi hingga akhirnya Raja Indra Bumaya dapat dikalahkan oleh Putra Ibrahim Basari yang tak lain adalah putra dari Sultan Ahmad Mansyur. Kedua kerajaan akhirnya disatukan setelah Putra Ibrahim Basari menikah dengan Putri Indra Dewi. Kedamaian akhirnya terwujud dengan menyatunya dua kerajaan tersebut.

Itulah gambaran pementasan Kemidi Rudat yang menjadi dasar pengambilan data dalam penelitian ini. Data-data nilai yang ditemukan dalam pementasan kemidi Rudat adalah (1) nilai religius yang berupa nilai akidah, ibadah dan muamallah; (2) nilai filosofis berupa filosofi yang berkaitan dengan budaya dan kearifan masyarakat Sasak Lombok, yaitu filosofi Sang Pemilik (epe aik), filosofi Tanah Air (gumi paer), dan filosofi kekayaan budi pekerti (budi kaye); (3) nilai etis yang berupa nilai kepatutan dan kerja keras, kepatuhan dan disiplin, dan nilai etis kepacuan atau ketekunan; (4) sedangkan yang terakhir, yaitu nilai estetis yang berupa wujud atau rupa, bobot atau isi, dan yang terakhir adalah nilai estetis dalam hal penampilan atau penyajian pementasan Kemidi Rudat Lombok.

Nilai religius tersebut kaitannya dengan sistem nilai masyarakat Sasak, yakni tindih, maliq, dan merang dijelaskan sebagai berikut. Sistem nilai dasar tindih dimanifestasikan dalam rasa tunduk dan taat pada aturan agama. Berdoa bersama yang dipimpin sesepuh Kemidi Rudat merupakan keinginan untuk menjadi insan yang baik, taat, soleh sesuai dengan tuntunan agama Islam. Para pemain Kemidi Rudat tetap komitmen pada aturan permainan (sebelum, saat, dan sesudah permainan) sebagai bentuk konsistensi pada kebenaran, kebaikan, keindahan, dan keluhuran nilai dalam Kemidi Rudat yang ditampilkannya.

Pantang bagi para pemain Kemidi Rudat untuk tidur dengan istrinya semalam sebelum pentas Kemidi Rudat dilaksanakan. Ini adalah manifestasi nilai penyangga dalam masyarakat Sasak yang disebut maliq. Jika pantangan itu dilanggar, maka akan banyak terjadi kesalahan dalam pementasan Kemidi Rudat yang dilaksanakan. Pementasan Kemidi Rudat desa Terengan harus 
dilakukan dengan menghadap ke selatan. Maliq untuk menghadap selain ke selatan. Konsekuensi yang sama akan terjadi jika itu dilanggar, yaitu banyak kesalahan dalam pementasan Kemidi Rudat, baik lagu maupun geraknya.

Aturan permainan tersebut di atas wajib dilaksanakan agar pementasan Kemidi Rudat yang dilakukan berjalan dengan baik dan sukses. Kesuksesan itu merupakan kebahagiaan bersama bagi para pemain rudat. Sebaliknya, jika pantangan dilanggar dan terjadi kesalahan, kesalahan itu juga merupakan kesalahan bersama yang ditanggung oleh semua pemain Kemidi Rudat, bahkan juga oleh seluruh warga Terengan. Sikap merasakan bersama baik bahagia maupun kesusahan akibat melanggar pantangan ini adalah manifestasi sistem nilai solidaritas sosial masyarakat Sasak yang disebut merang. Sikap dan kepercayaan masyarakat ini menunjukkan rasa iman dan takwanya kepada Allah dan kepercayaan terhadap hal-hal gaib yang dapat mendatangkan kebaikan maupun kesusahan.

Masyarakat Sasak yang mayoritas beragama Islam meyakini dan mengimani bahwa Islam adalah jalan kebenaran, kebaikan, dan keluhuran agar menjadi insan yang di ridhoi sikap dan kelakuannya di hadapan Allah Swt. Inilah manifestasi sikap tindih sebagai nilai dasar dalam masyarakat Sasak. Hal itu menumbuhkan sikap fanatisme terhadap Islam sebagai agama terbaik di sisi Allah Swt. Sikap fanatisme terhadap islam ini adalah manifestasi sikap maliq dan merang sebagai nilai penyangga dalam sistem nilai dasar masyarakat Sasak.

Dalam nilai filosofis, ungkapan epe-aik bermakna yang maha kuasa atas segala asal kejadian alam dan manusia. Allah Swt. adalah zat utama sebagai awal kejadian alam semesta beserta isinya dan penentu kehidupan dan kematian. Filosofi epe-aik ini bermakna kepatuhan dan ketakwaan kepada kekuasaan pemilik alam semesta, Allah Tuhan Yang Maha Esa, menegakkan ajaran agama, dan persamaan hak sebagai manusia di hadapan Allah. Kemidi Rudat menyajikan nilai ini melalui lagu dan dialog-dialog yang mereka ucapkan dalam pementasan.

Gumi paer yang secara umum disebut paer adalah rumusan simbolik pemahaman masyarakat Sasak tentang ruang dalam perspektif budaya. Dalam konsep gumi paer terakomodasi seluruh konsep yang berkaitan dengan permukaan bumi dengan segala yang ada di atasnya, segala isi bumi dan langit yang menaunginya. Konsep paer mencakup aspek-aspek kosmologis, konsep antropologis dan konsep sosiologis yang dipandang sebagai suatu kesatuan dalam budaya Sasak. Pementasan Kemidi Rudat yang dilaksanakan dalam 
rangka berhasilnya panen adalah ungkapan rasa syukur karena alam telah memberikan yang berharga bagi manusia yang memanfaatkannya.

Budi kaye merupakan frase bahasa Sasak yang menyiratkan simbol kekayaan diri pribadi manusia Sasak yang muncul dari kesadaran akan budi daya atau kekuasaan Illahi yang menurunkan akal budi. Potensi atau kekayaan akal budi inilah yang harus dimanfaakan dalam interaksi antarsesama manusia hingga tercipta kehidupan yang damai yang terakumulasi dalam nilai-nilai kearifan lokal masyaraka Sasak dalam bentuk Solah Soleh Soloh Repah Reme. Hidup yang dinaungi kebaikan, kesalehan, kedamaian dalam kebersamaan dan saling pengertian yang mendalam. Budi pekerti dan sikap yang baik yang ditunjukkan dalam Kemidi Rudat menjadi cermin pekerti agar kehidupan dapat berjalan dengan penuh kedamaian. Perilaku Putra Ibrahim Basari adalah contoh yang baik dan dapat menjadi cermin kehidupan yang baik dan beradab.

Konsep etis dan estetis tradisional yang membangun karya-karya seni tradisional Sasak adalah Semaiq dan Paut-kesederhanaan dan kepantasantetapi bukan berarti tidak memperhatikan detail dan ketuntasan dalam berekspresi. Paut mengandung makna sesuai dengan nilai-nilai etis, antara lain jujur dalam berekspresi, karya yang sejalan dengan kepribadian senimannya, realistik, dan tidak bertentangan dengan norma susila. Semaiq mengandung pengertian tidak mengada-ada dan tidak berlebihan, tetapi dapat dinikmati dan ditangkap maknanya. Konsep ini berlaku untuk seluruh aspek kesenian termasuk Kemidi Rudat Lombok.

Dalam bidang sosial budaya, etika dan moral kepatutan dan kerja keras (pacu) sangat dijunjung tinggi. Kepatutan dalam arti luas dapat ditemukan maknanya pada kata-kata atau ungkapan, seperti bender (lurus), las (ikhlas), polos (jujur), wanen (pemberani), dana darma (murah hati), soloh grasaq (ramah-tamah), solah seleh (baik, indah), priyak aseq (welas asih), bau asaq bau bateq (saling memberi dan menerima), wirang (punya rasa malu), meserah (tawakkal), nyandang (sesuai), onang (pantas), kenaq (benar), cumpu (setuju), teger (berketetapan hati), dan teguq (kuat).

Kepatutan perilaku sehubungan dengan dan peran di dalam masyarakat amat diperhatikan oleh orang Sasak. Perilaku yang tidak tepat atau tidak patut dianggap sebagai tanda kekurangan adab. Unsur-unsur kaidah interaksi antaranggota masyarakat sebagai suatu kesepakatan sosial diwujudkan ke dalam sejumlah sarana berkenaan dengan berbagai arena kehidupan manusia. Sejumlah sarana penanda posisi sosial juga telah dikembangkan dalam 
70| Mabasan - Vol. 5, No. 2, Juli-Desember 2011

kebudayaan Sasak. Tata cara penggunaan bahasa dan penyapaan, tata cara pengambilan sikap tubuh dan penempatan diri, tata cara berbusana, dan lain-lain berfungsi sebagai sarana pembentukan, penanaman, maupun intensifikasi nilainilai budaya di dalam masyarakat. Nilai sentral terletak pada kepatutan, dan hanya kepatutanlah yang dapat menghadirkan rasa penerimaan bathin.

Nilai moral atau nilai patuh dan kepatuhan atau disiplin dalam masyarakat Sasak tercermin dalam kata-kata atau ungkapan, seperti tresna (kasih sayang), bhakti (berbakti), taat (taat), adung (mufakat), rema (gotongroyong), raqi (tenggang rasa), priatin (prihatin), tao (bijaksana), bareng mongkel atau bareng anyong (senasib sepenanggungan), segiling/segeleng/ segolong (seia-sekata). Nilai-nilai dalam ungkapan di atas dapat diumpai dalam banyak adegan pementasan Kemidi Rudat Lombok.

Nilai moral dan etis ketekunan serta keuletan kerja (pacu, kepacuan), tercermin dalam kata-kata atau ungkapan, seperti geger (bersemangat), genem (rajin, tekun), pasu (rajin), kencak (terampil), gina (senang dan kreatif), gasa (waspada), resik (bersih), sayaga (siaga), priyatna (waspada), selengara (luwes), apik (hati-hati), gancang (gesit dan cepat dalam bekerja). Dalam pementasan Kemidi Rudat, sikap-sikap di atas ditunjukkan oleh beberapa tokoh hingga patut dijadikan sebagai contoh atau teladan agar setiap usaha yang dilakukan akan beroleh manfaat sesuai yang diinginkan.

Pada hakikatnya, semua jenis nilai etis yang dijelaskan di atas berfungsi sebagai: (a) ukuran perbuatan seseorang untuk dikatakan baik atau tidak baik dalam kelompoknya; (b) orientasi atau pedoman seseorang untuk bertindak dalam rangka mencapai tujuan dan kebahagiaan hidup; (c) abstraksi dari suatu sistem sosial budaya masyarakat tertentu sebagai pendukung nilai etis tersebut; (d) alat atau media bagi kelompok untuk melakukan kontrol terhadap pola perilaku warga kelompok atau masyarakatnya (Horton and Hunt, 1984).

Dalam pementasan Kemidi Rudat, selain perilaku yang baik dan seharusnya dilakukan, terdapat juga beberapa sikap mental dan sikap hidup yang seharusnya dihindari untuk dilakukan oleh setiap orang agar kehidupannya tidak mengalami kehancuran dalam segala aspeknya, baik dalam kehidupan pribadi, keluarga, maupun kehidupan bernegara. Hal-hal tersebut adalah:

- Mentalitas rakus dan serakah

- Pembicaraan kotor

- Sikap amarah

- Sikap mendengki

- Sikap ambisi atau gila tahta
- Sikap bakhil dan cinta harta yang berlebihan

- Cinta dunia yang berlebihan

- Sikap congkak atau sombong

- Sikap takjub atau bangga diri 
Sikap-sikap dan mental yang harus dihindari di atas adalah contoh yang tidak baik dari pementasan kemidi Rudat yang ditunjukkan melalui tokoh Raja Indra Bumaya dari negeri Ginter Baya. Jadi, dalam Kemidi Rudat Lombok, selain menunjukkan nilai-nilai kebaikan, ditunjukkan juga hal-hal buruk yang harus dihindari sehingga penonton dapat mengambil manfaat dan tahu mana yang baik dan yang buruk.

Nilai estetis Kemidi Rudat dalam wujud atau rupa pementasan adalah estetis dalam hal struktur, busana/kostum yang dikenakan para pemain yang unik dengan paduan warna-warna terang dan menimbulkan kesan yang indah bagi penonton, posisi dan peran pemain menentukan sikap dan perilaku dalam permainan nantinya, komandan yang berdiri di sebelah kanan adalah tokoh baik dan bijaksana dan sebaliknya wakil komandan sebelah kiri adalah tokoh kafir dalam pementasan Kemidi Rudat nantinya. Gerak dan lagu-lagu yang dinyanyikan menimbulkan kesan indah bagi yang menikmatinya terutama lagulagu yang berisi sholawat yang dinyanyikan dengan penuh penghayatan yang diiringi musik yang merupakan perpaduan berbagai alat musik. Nada dan alunan mandolin dan biola merupakan musik dominan dalam pementasan Kemidi Rudat.

Dalam hal bobot atau isi, pementasan Kemidi Rudat, selain memberikan hiburan bagi penontonnya juga menyampaikan ajaran-ajaran etika moral yang dapat menjadi pedoman perilaku sehari-hari masyarakat penontonnya. Setelah menonton pementasan Kemidi Rudat, penonton diharapkan menemukan kepuasan dalam rangka pencerahan dan penyucian rohani. Penonton merasa gembira sekaligus merenungi kandungan isi yang disampaikan dalam pementasan Kemidi Rudat yang baru saja ditontonnya. Hal ini senada dengan teori katarsis yang diungkapkan Aristoteles yang berbunyi: kepuasan menyaksikan seni drama dan mendengarkan musik bagi penonton dan pendengarnya merupakan 'penyucian' atau 'penyembuhan' rohani.

Bakat dan talenta merupakan bagian nilai estetis yang penting. Pemain atau tokoh-tokoh dalam pementasan Kemidi Rudat, khususnya yang berada di kampung terengan mewarisi bakat yang diturunkan oleh orang tua atau leluhur dalam satu garis keturunan. Artinya, jika sekarang seorang pemain memerankan tokoh raja atau sultan, berarti orang tua (bapak atau kakeknya) dahulu juga berperan sebagai raja atau sultan. Begitu juga dengan tokoh-tokoh lainnya. Akan tetapi, tetap melalui latihan-latihan rutin, terutama menjelang pementasan sebagai penyatuan dan pemantapan gerak. 
Keberhasilan pementasan juga diperoleh dengan dukungan media untuk mengajak penonton menghayati cerita dan merasa terlibat di dalamnya. Keberadaan layar belakang bergambar balairung istana akan menggiring penonton bahwa adegan sedang berlangsung di istana kerajaan. Begitu juga dengan gambar hutan dan taman bunga. Hal yang sama berlaku juga pada berbagai macam makanan yang digantung di atas panggung ketika drama Kemidi Rudat akan dimulai. Gantungan makanan itu membuat penampilan Jongos dan Khadam akan semakin maksimal karena dimanfaatkan untuk membuat adegan-adegan lucu yang membuat penonton tertawa. Tokoh Jongos dan Khadam yang diberi kebebasan bergerak akan leluasa memanfaatkan makanan yang tergantung tersebut sebagai alat akting yang dapat menghibur penonton karena peran mereka dalam cerita ini adalah peran penghibur. Keberhasilan menghibur Kemidi Rudat juga sangat ditentukan oleh penampilan dua tokoh pembantu kerajaan ini. Dengan dukungan media tersebut, penampilan para pemain Kemidi Rudat akan lebih maksimal dan memberikan kepuasan bathin bagi khalayak yang menonton. Media ini adalah dukungan estetis bagi pemain dan penonton Kemidi Rudat.

\section{Simpulan dan Saran}

Kemidi Rudat merupakan salah satu jenis teater tradisional yang tumbuh dan berkembang di Lombok. Teater tradisional ini merupakan perkembangan dari seni burdah dan zikir saman dan termasuk dalam bagian seni melayu Islam. Karena bercorak Islam sebagai agama yang dianut oleh mayoritas masyarakat Sasak Lombok, kesenian ini dengan cepat berkembang. Perkembangan ini juga tidak lepas dari peran Kemidi Rudat ini sebagai media hiburan dan dakwah, sebagai media penyampaian nilai-nilai kebaikan yang dapat dijadikan sebagai pedoman menjalani kehidupan sehari-hari bagi masyarakat Sasak Lombok.

Nilai-nilai budaya yang diekspresikan melalui media Kemidi Rudat ini mencakup nilai religius, nilai filosofis, nilai etis, dan nilai estetis. Nilai religius melingkupi nilai akidah, nilai ibadah, dan nilai muamallah. Nilai filosofis melingkupi filosofi pengabdian kepada Tuhan sebagai pemilik (epe aik) jagad raya beserta isinya, filosofi pemanfaatan bumi dan isinya (gumi paer) dengan bekerja keras dan tidak merusak alam, dan terakhir filosofi pemanfaatan akal budi (budi kaye), kekayaan budi pekerti yang muncul dari kesadaran akan kekuasaan Illahi yang menurunkannya kepada manusia. Kekayaan budi ini yang 
harus dimanfaatkan dan diwujudkan dalam kehidupan sehari-hari agar tercipta kehidupan yang damai dan indah. Nilai etis melingkupi kepatutan dan kerja keras, kepatuhan dan disiplin, serta kepacuan dan ketekunan. Terakhir adalah nilai estetis yang melingkupi nilai-nilai estetis dalam hal wujud atau rupa pementasan Kemidi Rudat, bobot atau isi Kemidi Rudat, dan nilai estetis dalam hal penyajian atau penampilan pementasan Kemidi Rudat.

Pembahasan nilai-nilai budaya yang ditemukan dalam penelitian ini dihubungkan juga dengan nilai-nilai budaya Sasak yang tertulis dalam kitab "Tapel Adam", yaitu kitab tembang suluk berbahasa Sasak yang berisi kearifan lokal masyarakat Sasak dalam menjalani kehidupan, menjelaskan bagaimana orang Sasak berhubungan dengan Tuhan, sesama manusia, dan bagaimana memperlakukan dan berhubungan dengan alam semesta.

Semua nilai-nilai budaya sasak yang disajikan dalam penelitian ini layak dijadikan sebagai pedoman perilaku bagi masyarakat Sasak. Nilai-nilai tersebut senada dengan prinsip-prinsip hukum adat dan kearifan lokal masyarakat Sasak dalam adat tapsila. Jika nilai-nilai tersebut dapat diwujudkan dalam kehidupan sehari-hari, niscaya akan tercipta kedamaian dan keindahan dalam hidup bermasyarakat dan bernegara, terutama bagi masyarakat Sasak Lombok. Kemidi Rudat sebagai salah satu media penyampaian nilai-nilai tersebut juga layak mendapat perhatian sehingga dapat terus bertahan dan berdaya guna.

Hasil penelitian ini mempunyai signifikansi dalam aspek teoretis, praktis, edukatif, dan aspek apresiatif. Oleh karena itu, disarankan kepada peneliti selanjutnya, pemerintah, penyelenggara dan pemerhati pendidikan dan kebudayaan untuk membaca, memperhatikan, dan menindaklanjuti hasil penelitian ini.

Berkaitan dengan aspek teoretis, disarankan kepada peneliti bahasa dan kebudayaan, khususnya kebudayaan daerah agar menjadikan model teori dan metode penelitian ini sebagai salah satu model penelitian bahasa, sastra, dan kebudayaan daerah. Teori hermeneutika sebagai alat analisis sangat membantu dalam meneliti kebudayaan daerah yang terus berkembang. Kepada peneliti yang ingin kembali meneliti Kemidi Rudat, disarankan agar meneliti lebih mendalam tentang aspek historis masuk dan berkembangnya Kemidi Rudat di Lombok.

Dalam hal aspek praktis edukatif, disarankan kepada para pengambil kebijakan dalam bidang pendidikan agar memberikan tempat bagi 
74| Mabasan - Vol. 5, No. 2, Juli-Desember 2011

pengembangan sastra dan kebudayaan daerah dalam kurikulum pendidikan, baik pendidikan dasar, menengah maupun pendidikan tinggi. Selain itu, kepada pengambil kebijakan di daerah Nusa Tenggara Barat, Lombok khususnya agar dapat menjadikan hasil penelitian ini sebagai bahan pengajaran kearifan lokal masyarakat Sasak, khususnya dalam pendidikan dasar sehingga anak-anak dari awal sudah mengenal kebudayaannya sendiri yang agung dan mempunyai tanggung jawab untuk mempertahankannya.

Terakhir, dalam aspek apresiatif, disarankan kepada para pengambil kebijakan bidang kebudayaan agar memperhatikan nilai-nilai yang terkandung dalam Kemidi Rudat yang meliputi nilai religius, nilai filosofis, nilai etika, dan nilai estetika sehingga dapat dijadikan sebagai salah satu bahan apresiasi dan referensi kebudayaan masyarakat Sasak Lombok. Selain itu, kepada siapapun yang berkenan membaca hasil penelitian ini, semoga dapat dijadikan sebagai salah satu sarana untuk lebih mengenal suku Sasak, baik kehidupan maupun kebudayaannya, melalui teater tradisional melayu Islam bernama Kemidi Rudat.

\section{DAFTAR PUSTAKA}

Agus Fathurrahman, H. Lalu. 2007. Menuju Masa Depan Peradaban. Refleksi Budaya Etnik di NTB. Yogyakarta: Genta Press.

Agus Fathurrahman, H. Lalu. 2009. Lombok Style: Kumpulan Tulisan Kebudayaan Sasak. Belum diterbitkan.

Ahimsa-Putra, Heddy Shri. 1998. Teks dalam Konteks Seni: Seni dalam Kajian Antropologi Budaya. Dalam SENI: Jurnal Pengetahuan dan Penciptaan Seni, vol. VI:01 Mei 1998. Yogyakarta: BP ISI

Ahyar Fadly, M. 2008. Islam Lokal: Akulturasi Islam di Bumi Sasak. BaguLombok Tengah: STAIIQ Press.

Al-Jazairi, Abu Bakar. 2001. Pemurnian Akidah. Terjemahan Sahid HM. Jakarta: Pustaka Amani.

Amir, Hazim. 1986. Nilai-Nilai Etis dalam Wayang dan Pendidikan Watak Guru. Disertasi tidak diterbitkan. Malang: PPS IKIP Malang. 
Amirin, Tatang M. 1986. Menyusun Rencana Penelitian. Jakarta: Rajawali

Arifin. Olah Akal Budi. Dasar-Dasar Logika dan Filsafat Ilmu. Yogyakarta: Penerbit Lilin.

Arikunto, Suharsimi. 2002. Prosedur Penelitian (Suatu Pendekatan Praktek). Jakarta: Rineka Cipta

Astiyanto, Heniy. 2006. Filsafat Jawa. Menggali Butir-Butir Kearifan Lokal. Yogyakarta: Warta Pustaka.

Badrun, A. M. dkk. 2004. Garis Tepi Masyarakat NTB. Membongkar Nalar Sosial, Budaya dan Pembangunan di NTB. Mataram: InSKRIP NTB.

Bagus, Lorens. 2002. Kamus Filsafat. Jakarta: Gramedia.

Bakker S.J., J.M.W.. 1984. Filsafat Kebudayaan: Sebuah Pengantar. Yogyakarta: Kanisius.

Bandem, I Made. 1988. Teater Daerah di Indonesia. Yogyakarta: Fajar Pustaka.

Bartholomew, John Ryan. 2001. Alif Lam Mim. Kearifan Masyarakat Sasak. Yogyakarta: PT Tiara Wacana.

Budi Santoso, Iman. 2008. Mutiara Kearifan Nusantara. Yogyakarta: Penerbit Riak.

Budiwanti, Erni. 2000. Islam Sasak. Yogyakarta: Lkis dan Yayasan Adi Karya dan Ford Foundation.

Christomy, T \& Untung Yuwono. 2004. Semiotika Budaya. Depok: Pusat Penelitian Kemasyarakatan dan Budaya Direktorat Riset dan Pengabdian Masyarakat Universitas Indonesia.

Dananjaya, James.1983. Fungsi Teater Rakyat Bagi Bangsa Indonesia. Dalam Seni dalam Masyarakat Indonesia, Edy Sedyawati dan Sapardi Djoko Damono ed. Jakarta: Gramedia.

Dharsono (Sony Kartika). 2007. Estetika. Bandung: Rekayasa Sains.

Dibia, I Wayan. 1993. Seni Pertunjukan dan Sumbangannya dalam Pembinaan Kepribadian Bangsa. Dalam Kebudayaan dan Kepribadian Bangsa. Tjok Rai Sudharta et al. Denpasar: Upada Sastra. 
76| Mabasan - Vol. 5, No. 2, Juli-Desember 2011

Djelantik, A.A.M. 2001. Estetika, Sebuah Pengantar. Yogyakarta: Masyarakat Seni Pertunjukan Indonesia.

Eaton, Marcia Muelder. 2010. Persoalan-Persoalan Dasar Estetika. Jakarta: Salemba Humanika.

Fithrorozi. 2008. Mengenal Seni Rudat, (Online), (http://www.rumahdunia.net/ wmview.php?ArtID=1191), diakses tanggal 20 Desember 2010.

Frondizi, Risteri. 1963. Pengantar Filsafat Nilai. Terjemahan Cut Ananta Wijaya. 2001. Yogyakarta: Pustaka Pelajar.

Gadamer, Hans Georg. 2004. Kebenaran dan Metode. Pengantar Filsafat Hermeneutika. Diterjemahkan oleh Ahmad Saidah. 1975. Yogyakarta: Pustaka Pelajar.

Geertz, Clifford. 1992. Tafsir Kebudayaan. Yogyakarta: Kanisius.

Gie, The Liang. 1978. Garis Besar Filsafat. Yogyakarta: Super Sukses.

Gie, The Liang. 1983. Garis Besar Estetika. Yogyakarta: super Sukses.

Hamid, Abdul Wahid. 2001. Islam Cara Hidup Alamiah. Yogyakarta: Lazuardi.

Haq, M. Zaairul. 2009. Tasawwuf Semar hingga Bagong. Simbol, Makna, dan Ajaran Makrifat dalam Panakawan. Yogyakarta: Kreasi Wacana.

Jauhari, Heri. 2010. Cara Memahami Nilai Religius dalam Karya Sastra. Bandung: Arfino Raya.

Kattsoff, Louis O. 2004. Pengantar Filsafat. Yogyakarta: Tiara Wacana.

Kayam, Umar. 1981. Seni, Tradisi, Masyarakat. Jakarta: Sinar Harapan.

Kayam, Umar. 2000. Kelir Tanpa Batas (Faruk, Ed.). Jakarta: Perpustakaan Utan Kayu.

Koentjaraningrat. 1985. Pengantar Ilmu Antropologi. Jakarta: Aksara Baru.

Koentjaraningrat. 1985. Persepsi Masyarakat terhadap Kebudayaan Nasional. Persepsi Masyarakat terhadap Kebudayaan. Jakarta: Gramedia.

Koentjaraningrat. 1997. Manusia dan Kebudayaan di Indonesia. Jakarta: Penerbit Djambatan. 
Nilai-Nilai Budaya Sasak Kemidi Rudat Lombok...(Murahim)

Kuntowijoyo. 2006. Budaya dan Masyarakat. Yogyakarta: Tiara Wacana.

Madjid, N. 2000. Masyarakat Religius. Jakarta: Paramadina.

Magnis Suseno, Franz. 1992. Filsafat sebagai Ilmu Kritis. Yogyakarta: Kanisius.

Maryaeni. 2005. Metode Penelitian Kebudayaan. Jakarta: Bumi Aksara.

Moleong, Lexi J. 2006. Metodologi Penelitian Kualitatif (Edisi Revisi). Bandung: PT. Remaja Rosdakarya Offset.

Mudjia Raharjo. 2008. Dasar-Dasar Hermeneutika. Antara Intensionalisme \& Gadamerian. Yogyakarta: Ar-Ruzz Media Group.

Muzir, Inyiak Ridwan. 2010. Hermeneutika Filosofis Hans-Georg Gadamer. Yogyakarta: Ar-Ruzz Media Group.

Nasr. 1993. Spiritualitas dan Seni Islam. (Terjemahan Rahmani Astuti). Bandung: Penerbit Mizan.

Palmer, Richard. E. 1969. Hermeneuties. Evantson: Northwestern University Press.

Poespoprodjo. 2004. Hermeneutika. Bandung: Pustaka Setia.

Qayyim al-Jauziyah, Ibnu. 2000. Etika Kesucian. Wacana Penyucian Jiwa Entitas Sikap Hidup Muslim. Surabaya: Risalah Gusti.

Qoyyim, Ibnu. 2000. Pendefinisian Kembali Tradisi dan Identitas Etnik. Orang Sasak dan Kemidi Rudat. Jakarta: LIPI.

Sachari, Agus. 1989. Estetika Terapan: Spirit-Spirit yang Mendekam. Bandung: Nova.

Salad, Hamdi. 2000. Agama Seni: Refleksi Teologis dalam Ruang Estetik. Yogyakarta: CV. Adipura

Saryono, Djoko. 2002. Hermeneutika Sebagai Piranti Analisis Dimensi Nilai Budaya (dari) Karya Sastra. Belum diterbitkan.

Saryono, Djoko. 1987. Representasi Nilai Budaya Jawa dalam Prosa Fiksi Indonesia. Disertasi tidak diterbitkan. IKIP Malang. 
78| Mabasan - Vol. 5, No. 2, Juli-Desember 2011

Satoto, Sudiro. 1994. Teater Sebagai Sistem Tanda: Sebuah Pengantar. Jakarta: Grasindo.

Saukah, Ali, dkk. 2010. Pedoman Penulisan Karya Ilmiah (edisi kelima). Malang: Penerbit Universitas Negeri Malang.

Schwartz, S. H. \& Bilsky, W. (1987). Toward a Universal Psychological Structure of Human Values.Journal of Personality and Social Psychology, 53, 550-562.

Sedyawati, Edi. 1981. Pertumbuhan Seni Pertunjukan. Jakarta: Sinar Harapan.

Sedyawati, Edi. 2010. Budaya Indonesia: Kajian Arkeologi, Seni, dan Sejarah. Jakarta: PT. RajaGrafindo Persada.

Sikki, Muhammad. 1991. Nilai-Nilai Budaya dalam Sastra Daerah Sulawesi Selatan. Pusat Pembinaan dan Pengembangan Bahasa. Depdikbud, Jakarta.

Siradz, Umar,dkk. 1995/1996. Wujud, Arti dan Fungsi Puncak-Puncak Kebudayaan Lama dan Asli Bagi Masyarakat Pendukungnya di Daerah NTB: Sumbangan Kebudayaan Daerah Terhadap Kebudayaan Nasional. Mataram: Depdikbud Provinsi NTB.

Soedarsono, R.M. 1999. Metodologi Penelitian Seni Pertunjukan dan Seni Rupa. Yogyakarta: arti.line.

Soekanto, Soerjono. 2008. Hukum Adat Indonesia. Jakarta: PT. RajaGrafindo Persada.

Soemanto, Bakdi. 2001. Jagat Teater. Yogyakarta: Media Pressindo.

Sudirga, I Komang. 2005. Cakepung: Ansambel Vokal Bali. Yogyakarta: Kalika Press.

Sugiyono, Prof. Dr. 2007. Memahami Penelitian Kualitatif. Bandung: cv. Alfabeta

Sumaryono, E. 1999. Hermeneutika: Sebuah Metode Fisafat. Yogyakarta: Kanisius.

Suparman, L.Gde.,dkk. 1996/1997. Pengungkapan Nilai Budaya Naskah Kuno Kotaragama. Jakarta: Departemen Pendidikan dan Kebudayaan RI

Sutrisno, Mudji \& Hendar Putranto, ed. 2005. Teori-Teori Kebudayaan. Yogyakarta: Kanisius 
Taufik, 2008. Sejarah Kesenian Rudat, (Online), (taufik.blogspot.com/rudat/), diakses tanggal 20 Desember 2010.

Titscher, Stefan dkk. 2009. Metode Analisis Teks \& Wacana. Prof. Dr. Abdul Syukur Ibrahim (ed.). Yogyakarta: Pustaka Pelajar.

Tolomundu, Farid \& Moh. Yamin. 2008. Besiru! Revitalisasi Banjar di Lombok. Mataram: Nala Cipta Litera.

W.M, Abdul Hadi. 2004. Hermeneutika, Estetika, dan Religiusitas. Esai-esai Sastra Sufistik dan Seni Rupa. Yogyakarta: Mahatari.

Widianto, Bambang \& Pirous. 2009. Perspektif Budaya. Kumpulan Tulisan Koentjaraningrat Memorial Lectures I-V/2004-2008. Jakarta: PT. RajaGrafindo Perkasa.

Wiwien, Widyawati R. 2010. Etika Jawa. Menggali Kebijaksanaan dan Keutamaan Hidup Lahir Bathin. Yogyakarta: Pura Pustaka.

Vos, H. de. 1987. Pengantar Etika. Yogyakarta: Tiara Wacana.

Zakaria, Fath. 1998. Mozaik Budaya Orang Mataram. Mataram: Yayasan Sumurmas Al-Hamidy. 